\title{
Non-Diapiric Salt Domes in the West Zanjan, Central Iran
}

\author{
Sina Alizadeh \\ Department of Geology, Islamic Azad University, Science and Research Branch, Tehran, Iran \\ Email: c.alizadeh@yahoo.com
}

How to cite this paper: Alizadeh, S. (2017) Non-Diapiric Salt Domes in the West Zanjan, Central Iran. Open Journal of Geology, 7, 132-146. https://doi.org/10.4236/ojg.2017.72009

Received: September 16, 2016 Accepted: February 21, 2017 Published: February 24, 2017

Copyright (C) 2017 by author and Scientific Research Publishing Inc. This work is licensed under the Creative Commons Attribution International License (CC BY 4.0).

http://creativecommons.org/licenses/by/4.0/

\begin{abstract}
The salt domes of the west Zanjan (Central Iran) are the most important structures in the study area. They have been formed by the uplifting and erosion together under low humidity and dry and warm climate condition. The salt rocks with near to 200 meters thickness are related to lower member of the Upper Red Formation (Early Miocene) that deposited in the inverted back arc basin. They have been formed in the Central Iran basin after the ArabianEurasian convergence. Based on filed works and preparation of geologic map, salt domes have been cropped out during regional uplifting and erosion along hinge zone of a longitudinal anticline. Also, there is no evidence for salt diapirism and so, they are different from some salt diapirs in the southwestern margin of Zanjan that is investigated by other researchers.
\end{abstract}

\section{Keywords}

Non-Diapiric, Salt Dome, Zanjan, Central Iran

\section{Introduction}

The Miocene gypsiferous rocks are named Upper Red Formation by the National Iranian Oil Company geologists [1]. Its thickness in the type section, near Qom city, is about $3000 \mathrm{~m}$ and comprises alternations of red fine-grained sandstones, compact gypsum, conglomerate and marly sandstones. The Upper Red Formation overlies the Qom Formation but, in some parts of NW and Central Iran, the contact comprises thick salt and gypsum [1]. The Miocene Upper Red Formation in the study area was deposited in a Marine regression condition (firstly) and fluvial system under dry and warm climatic condition (later) [1]. Salt domes or positive topographical features which have been formed by evaporate minerals (mainly halite) are the index structures in Upper Red Formation [2].

There are many salt domes most of which have been cropped out and the aim 
of this study is to determine diapiric or non-diapiric condition of salt domes in the Zanjan area, Iran.

\section{Geologic Setting}

Iran country has composed from different plates: Arabian plate in south and west (Zagros and Persian Gulf), Cimmerian miniplate in north and east, Eurasian plate in northeast margin [3] [4]. There are three physiographic-tectonic zones that have salt rocks: 1) Zagros Mountain, 2) Persian Gulf basin and 3) Cental Iran basin on which the study area is situated. Dominant structural trends in Central Iran are NW-SE in northwestern part and N-S in eastern part. The basement of the plateau consists of Cimmerian miniplate. Volcanics of late Cretaceous-early Miocene age in Central Iran represent Urmieh-Dokhtar magmatic arc. Volcanic rocks, evaporates and Turbidites successions up to $3 \mathrm{~km}$ thick represent Eocene back-arc extension across Central Iran [5].

This succession is commonly overlain in Central Iran by terrestrial clastics, evaporates and volcanics of the Lower Red Formation of Oligocene age. Marine deposition resumed across much of Central Iran with the carbonates of the largely lower Miocene Qom Formation. The Qom Formation is overlain by middle Miocene terrestrial clastics and evaporates of the Upper Red Formation. The salt deposits belonging to Cenozoic of Central Iran basin have two separate origins: The old type related to Upper Eocene deposits and Lower Red formation; and younger type related to Upper Red formation [5].

Based on previous research [2], the study area is situated in Urmieh-Dokhtar physiographic province (Figure 1). Dominant structural trend in Urmieh-Dokhtar province is NW-SE. From tectonics view, it contains a magmatic arc that is result of subduction to beneath of southern active continental margin of Cimmerian plate. Also, Sahand and other cones (about 9) in lesser Caucasus hinterland are result of quaternary magmatism in this zone that it has marked by widespread Eocene volcanism. Urmieh-Dokhtar Province has continued to south of Black Sea and its width has increased from Naien city that many parts have covered by quaternary deposits of Dagh Sorkh Kavir, Southern Urmieh Lake, Namak and Hoz-e Soltan Lakes have formed on it. So, there are a few backland basins with Playa type sedimentation because of dip decreasing in Ben off zone (in NW part of magmatic arc). SE part of magmatic arc has formed on southwest margin of East-Central Iran microcontinent [3].

\section{Material and Methods}

Salt domes of Iran have been presented by the large variety of shapes and elevation from high relief to entirely eroded structures. These different morphologies are controlled by various factors, for example, position related to other structures, the time of emergence, the rate of salt dissolution, which is controlled by the rate of erosion, the bulk rate of salt emission from the source layer, and provinces have distinguished in Iran and the study area has situated on Tasoj-Zanjan eventually by the tectonic activity [6]. Based on recent research [7], nine diapiric 


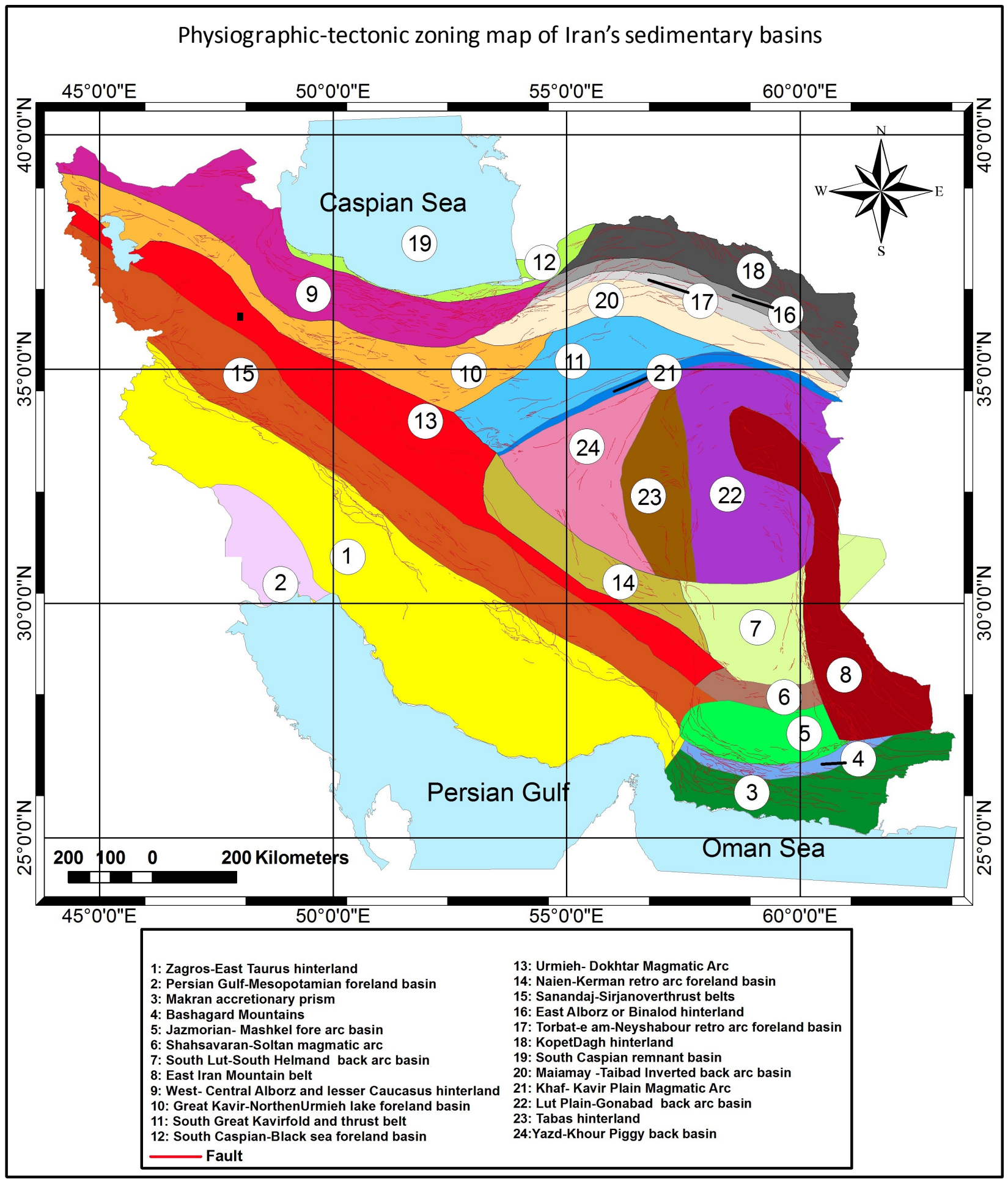

Figure 1. Physiographic-tectonic zoning map of Iran's sedimentary basins, modified from [2]. The study area is shown in the black rectangle.

Province.

The implemented studies indicate that the salts of this province are new type that cropped out along hinge zone of a burial longitudinal anticline on footwall of the Halab fault [8]. The salt domes of this province have occurred in an area 
covering about $10 \mathrm{~km}^{2}$. They have been covered by thin marl and separated from others by Quaternary deposits. The salt structures have not got diapiric cores, thus, they are not salt diapirs (Figure 2 and Figure 3).

Also, there is a saline brine (Figure 4) that flows to the plain (Figure 5) for traditional mineral processing by evaporation.

\section{Results and Discussion}

Salt domes in the study area have been caused by evaporation (Figure 6) and weathering of salt rocks under low humidity (about 15\%) and dry climate condition. The salt rocks of study area are related to the marine regression and evaporate conditions in inverted back arc basin (Central Iran). They are related to lower member $\left(\mathrm{M}_{1}\right)$ of Upper Red formation that has been under weathering now. Thus, they are different from other salt domes and diapirism in Iran that investigated by many researchers [9]-[20].

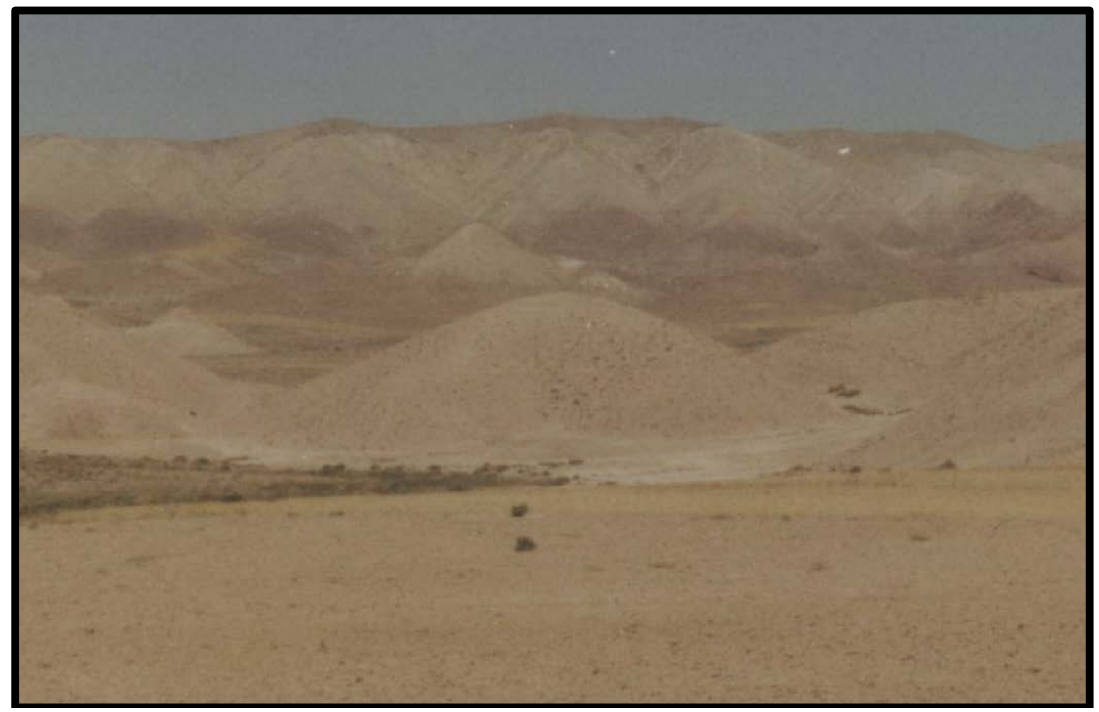

Figure 2. A far view (to NE) from some salt domes of the study area.

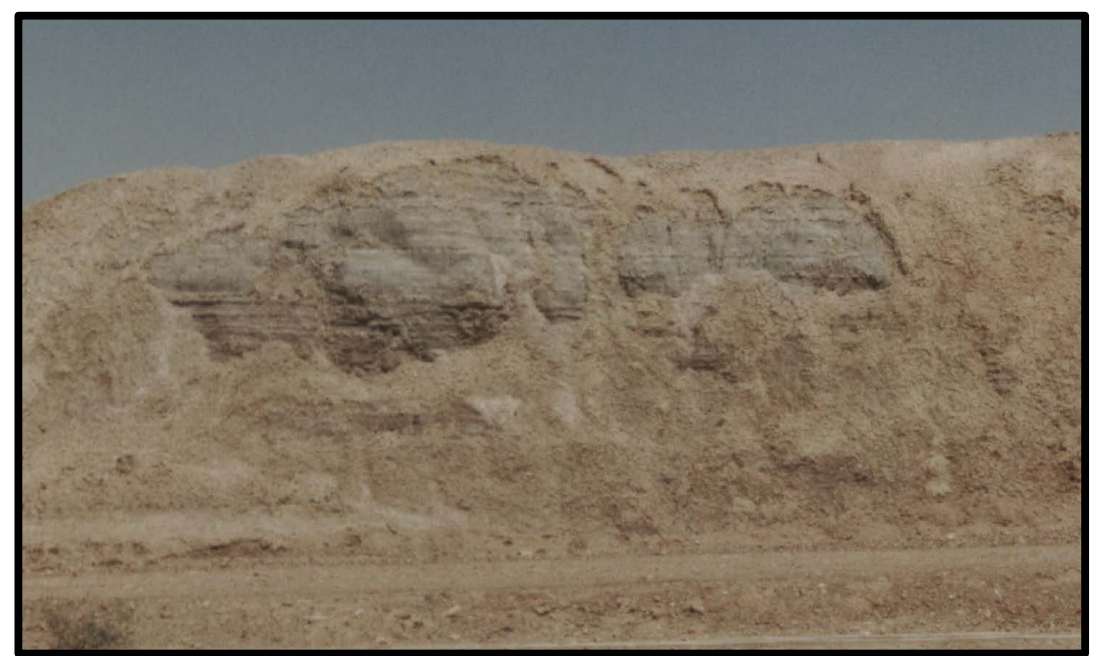

Figure 3. A near view from the horizontal salt rock of the study area. 


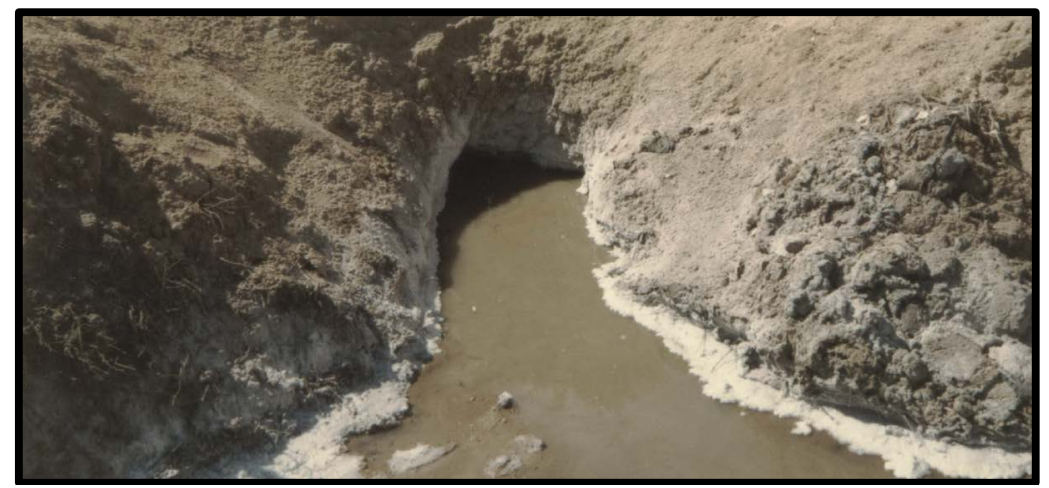

Figure 4. A saline brine in the southern part of study area.

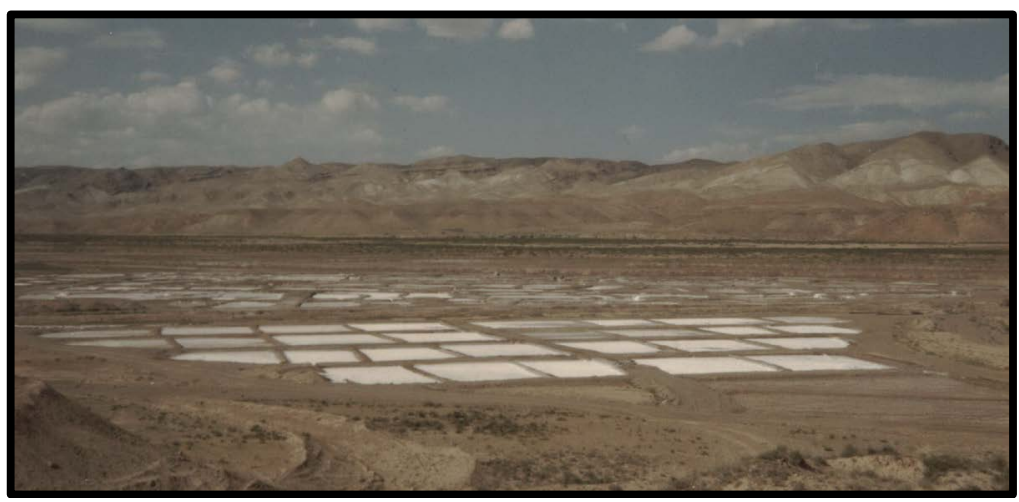

Figure 5. A view from evaporative pools in the study area.

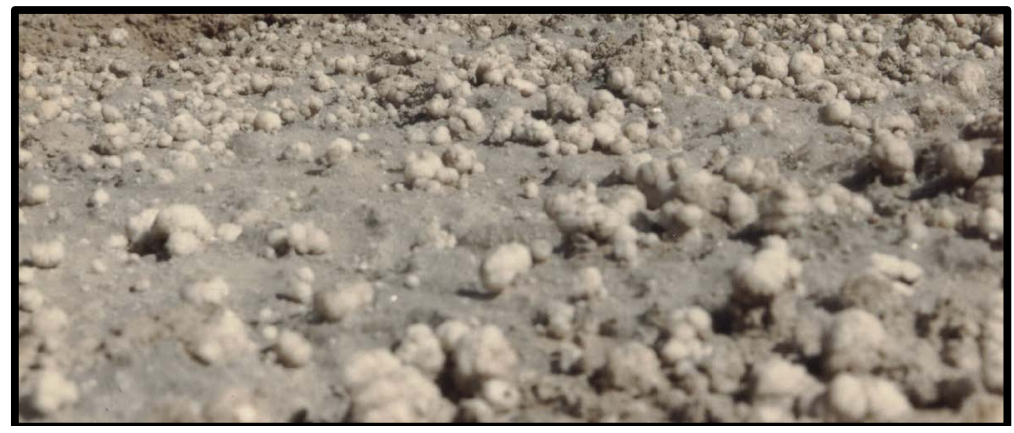

Figure 6. Salt deposition by evaporation of brine.

Based on previous work on the mud diapirism [21] [22] and neotectonic regime in Iran [23]-[28], Zagros in south Iran is the most active zone [29]-[69]. Then, Alborz [70]-[116] and Central Iran [117]-[145] have been situated in the next orders. Thus, salt domes in the study area have not been affected by regional shortening. The main characteristics of salt domes in the study area have summarized in Table 1.

\section{Conclusion}

The geologic map has prepared and based on field works on the salt domes of the west Zanjan (north Iran), salt rocks in the study area are caused by evaporation in the last marine regression condition. Then, their weathering under low 
Table 1. Main characteristics of salt domes in the study area.

\begin{tabular}{cc}
\hline Age of salt & Early Miocene \\
\hline Name of Formation & Upper Red \\
Thickness of salt rocks & Near to $200 \mathrm{~m}$ \\
Salt deposition Setting & Inverted back arc basin \\
Setting of Salt structures Evolution & Retro arc Basin \\
Folding Type & Open to Gentle \\
Humidity of the weather & Low \\
Salt dome Position & Hinge zone of anticline
\end{tabular}

humidity and dry climate condition has been formed individual salt domes. In the other words, the salt domes of study area are related to Miocene lower member of the Upper Red Formation that deposited in the inverted back arc basin. But they have been formed in the Central Iran retro arc basin. Therefore, they have been formed by the uplifting and regional shortening under dry and warm climate. There are some structures such as Halab fault and folds that cause the uplifting and cropping out of salt rocks. Thus, there is no evidence for salt diapirism and they are results of the uplifting and erosion together.

\section{Acknowledgements}

This work has been funded by the research project in Islamic Azad University, Science and Research Branch, Tehran, Iran. Also, special thanks to vice-president for research in Science and Research Branch, Tehran.

\section{References}

[1] Rafiei, B., Ahmadi Ghomi, F. and Shahkaram, M. (2011) Depositional Environments and Sequence Stratigraphy of the Fluvial Upper Red Formation (Miocene) in the Avaj Area, Qazvin Province, Iran. Neues Jahrbuch für Geologie und Paläontologie-Abhandlungen, 259, 257-270.

[2] Qorashi, M. and Arian, M. (2011) Tectonics of Iran. Geologic Survey of Iran, Tehran, $336 \mathrm{p}$.

[3] Arian, M. (2013) Physiographic-Tectonic Zoning of Iran's Sedimentary Basins. Open Journal of Geology, 3, 169-177. https://doi.org/10.4236/ojg.2013.33020

[4] Arian, M. (2011) Basement Tectonics and Geology of Iran. Asar Nafis Press, Qum, $300 \mathrm{p}$.

[5] Jackson, M.P.A., Cornelius, R.R., Craig, C.H., Gansser, A., Stocklin, J. and Talbot, J.C. (1990) Salt Diapirs of the Great Kavir, Central Iran. Geological Society of America Memoirs, 177, 1-150. https://doi.org/10.1130/mem177-p1

[6] Jahani, S., Callot, J.P., de Lamotte, F.D., Letouzey, J. and Leturmy, P. (2007) The Salt Diapirs of the Eastern Fars Province (Zagros, Iran): A Brief Outline of Their Past and Present. In: Lacombe, O., Roure, F., Lavé, J. and Vergés, J., Eds., Thrust Belts and Foreland Basins, Frontiers in Earth Sciences, 289-308.

https://doi.org/10.1007/978-3-540-69426-7_15

[7] Arian, M. and Noroozpour, H. (2015) Tectonic Geomorphology of Iran's Salt Structures. Open Journal of Geology, 5, 61-72. 
https://doi.org/10.4236/ojg.2015.52006

[8] Pourkermani, M. and Arian, M. (1999) Structural Analysis of Halab Fault. Proceeding of the 3 rd Symposium of Geological Society of Iran, Shiraz, 31 August-2 September 1999, 130-132.

[9] Arian, M. and Noroozpour, H. (2015) The Biggest Salt-Tongue Canopy of Central Iran. Open Journal of Geology, 5, 55-60. https://doi.org/10.4236/ojg.2015.52005

[10] Asadian, F., Pourkermani, M. and Arian, M. (2007) Tectonic Geomorphology of Salt Structures in the Garmsar-Lasjerd Area. Geographical Research, 39, 75-84.

[11] Pourkermani, M. and Arian, M. (1997) Salt Domes of Central Iran. Journal of Humanities, 3, 29-41.

[12] Arian, M. (2011) A Preface on Salt Diapirism of Iran. Asar Nafis Press, Qum, 309 p.

[13] Asadian, F. and Arian, M. (2009) Identification of Diapiric Provinces of Central Iran through Geological and Geographical Analysis. International Journal of Agriculture Environment \& Biotechnology, 2, 3443-3451.

[14] Arian, M. (2012) Clustering of Diapiric Provinces in the Central Iran Basin. Carbonates and Evaporites, 27, 9-18. https://doi.org/10.1007/s13146-011-0079-9

[15] Khodabakhshnezhad, A. and Arian, M. (2016) Salt Tectonics in the Southern Iran. International Journal of Geosciences, 7, 367-377. https://doi.org/10.4236/ijg.2016.73029

[16] Razaghian, G. and Arian, M. (2015) The Emergent Salt Diapirs in the East Zagros, Iran. Open Journal of Geology, 5, 718-726. https://doi.org/10.4236/ojg.2015.510063

[17] Arian, M. (2010) Tectonics and Sedimentation. Farazamin Press, Tehran, 307 p.

[18] Arian, M. and Maleki, Z. (2010) Principals of Experimental Tectonics. Asar Nafis Publication, Qum, 224 p.

[19] Pourkermani, M. and Arian, M. (1998) Tectonic Geomorphology of Salt Domes in West of Zanjan Province, Iran. Geographical Research, 47, 44-53.

[20] Arian, M. and Feizi, F. (2010) The Significance of Faulting on the Surficial Spreading of Evaporitic Deposits in the Varamin-Semnan Area. Journal of Earth and Resources, 3, 1-20.

[21] Feizi, F., Arian, M. and Arian, A. (2015) Mud Diapirism on the Makran, Iran: Case Study on the Napag Mud Volcano. Open Journal of Geology, 5, 300-308. https://doi.org/10.4236/ojg.2015.55027

[22] Arian, M. and Sistanipour, A. (2015) Mud Diapirism on the Gorgan, North Iran. Open Journal of Geology, 5, 442-450. https://doi.org/10.4236/ojg.2015.56041

[23] Arian, M. and Khodabakhshnezhad, A. (2015) Sedimentary Environments Can Be Changed by Geotechnology (Case Study: A Morphotectonic Idea for Design of Extensive Artificial Bay on the Iranian Plateau). International Journal of Geosciences, 6, 487-496. https://doi.org/10.4236/ijg.2015.65039

[24] Arian, M. (2011) Middle East Tectonics. Asar Nafis Press, Qum, 236 p.

[25] Arian, M. (2010) Applied Seismotectonics. Farazamin Press, Tehran, 304 p.

[26] Arian, M. and Maleki, R. (2008) Neotectonics. Farazamin Research Center, Tehran, 150.

[27] Pourkermani, M. and Arian, M. (1998) Seismicity of Iran. Shahid Beheshti University Press, Tehran, 212.

[28] Pourkermani, M. and Arian, M. (1997) Seismotectonics. DezAb Consulting Engineers Company Press, Tehran, 270.

[29] Arian, M. and Aram, Z. (2014) Relative Tectonic Activity Classification in the Ker- 
manshah Area, Western Iran. Solid Earth, 5, 1277-1291. https://doi.org/10.5194/se-5-1277-2014

[30] Mashal, M., PourKermani, M., Charchi, A., Almasian, M. and Arian, M. (2013) Pattern of Structural Geology Underground in Eastern of North Dezfol Embayment. Advances in Environmental Biology, 7, 260-268.

[31] Pazhoohan, M., Arian, M., Ghorashi, M. and Khosrotehrani, K. (2014) A Study of Drainage Pattern Responses to Active Tectonics in Tadvan Region, SW Iran. Geodynamics, 1, 36-41.

[32] Rahimi, N. and Arian, M. (2014) Tectonic Geomorphplogy of Kangavar-Sosangerd Region, West Iran. Advances in Environmental Biology, 8, 119-124.

[33] Arian, M. and Hashemi, A. (2008) Seismotectonic Zoning in the Zagros. Journal of Sciences, 18, 63-76.

[34] Arian, M., Ahmadnia, A., Qorashi, M. and Pourkermani, M. (2002) Structural Analysis of Mengharak Transcurrent Fault System in Zagros, Iran. Special GEO 2002 Conference Issue Geoarabia, 7, 209-210.

[35] Arian, M., Qorashi, M., Pourkermani, M. and Ahmadnia, A. (2003) Fractal Analysis of Mengharak Transcurrent Fault System in Zagros, Iran. Proceedings of the 4 th International Conference on Seismology and Earthquake Engineering, Tehran, 1214 May 2003, 23.

[36] Baharvand, S., Pourkermani, M., Ajalloian, R., Arian, M. and Nouryazdan, A.R. (2010) Seymareh Landslide and Its Role in Environmental and Geomorphologic Changes of the Pole-Dokhtar Area. Journal of the Earth, 4, 13-24.

[37] Abdideh, M., Qorashi, M., Rangzan, K. and Arian, M. (2011) Assessment of Relative Active Tectonics Using Morphometric Analysis, Case Study of Dez River (Southwestern, Iran). Geosciences, 20, 33-46.

[38] Arian, M., Qorashi, M., Pourkermani, M. and Ahmadnia, A. (2006) The Structural Significance Kareh Bas Transcurrent Fault System in the Zagros Fold and Thrust Belt. Geosciences, 15, 126-133.

[39] Arian, M. and Noroozpour, H. (2015) Seismic Activity and Fractal Geometry of Kareh Bas Fault System in Zagros, South of Iran. Open Journal of Geology, 5, 291-299. https://doi.org/10.4236/ojg.2015.55026

[40] Ehsani, J. and Arian, M. (2015) Quantitative Analysis of Relative Tectonic Activity in the Jarahi-Hendijan Basin Area, Zagros Iran. Geosciences Journal, 19, 1-15. https://doi.org/10.1007/s12303-015-0016-3

[41] Arian, M. and Mohammadian, R. (2011) Analysis of Fractures in the Asmari Reservoir of Marun Oil Field (Zagros, Iran). Geosciences, 20, 87-96.

[42] Tajali, S. and Arian, M. (2016) Petrophysical Evaluation and the Effect of Shale Layers on Net Pay Zone Thickness in the Marun Oil Field, Iran. Open Journal of Geology, 6, 763-773. https://doi.org/10.4236/ojg.2016.68059

[43] Arian, M., Qorashi, M. and Ahmadnia, A. (2003) Analysis of Behbahan Shear Zone. Iranian Journal of Geology, 1, 1-4.

[44] Omidali, M., Arian, M. and Sorbi, A. (2015) Neotectonics of Boroujerd Area, SW Iran by Index of Active Tectonics. Open Journal of Geology, 5, 309-324. https://doi.org/10.4236/ojg.2015.55028

[45] Chegini, A., Sorbi, A. and Arian, M. (2015) Active Tectonics of Hamedan Area, SW Iran by Index of Active Tectonics. International Journal of Geology, 4, 108-118.

[46] Maleki, Z., Arian, M., Solgi, A. and Ganjavian, M.A. (2014) The Elements of Fold Style Analysis in the Khaftar Anticline, Zagros, Iran. Open Journal of Geology, 4, 79-92. https://doi.org/10.4236/ojg.2014.43008 
[47] Maleki, Z., Arian, M. and Solgi, A. (2014) Structural Style and Hydrocarbon Trap of Karbasi Anticline, in the Interior Fars Region, Zagros, Iran. Solid Earth Discussions, 6, 2143-2167. https://doi.org/10.5194/sed-6-2143-2014

[48] Ehsani, J., Arian, M. and Ghorashi, M. (2015) Geomorphic Signatures of Active Tec-tonics in the Jarahi-Hendijan Drainage Basin in the South West Iran. Geosciences, 24, 211-218.

[49] Khodabakhshnezhad, A., Pourkermani, M., Arian, M., Matkan, A.A. and Charchi, A. (2015) Active Tectonics of Great Karounriver Basin. Geosciences, 24, 13-28.

[50] Maleki, Z., Arian, M., Solgi, A. and Ganjavian, M.A. (2015) Elements of Fold Style Analysis in the Karbasi Anticline, Interior Fars Region, Zagros. Geosciences, 24, 293-302.

[51] Baratpour, F., Arian, M. and Solgi, A. (2015) Geometric Analysis of Tukak and Kamarun Anticlines on Izeh Zone, Zagros. Geosciences, 24, 191-200.

[52] Gholamhosein Fard, N., Sorbi, A. and Arian, M. (2015) Active Tectonics of Kangavar Area, West Iran. Open Journal of Geology, 5, 422-441. https://doi.org/10.4236/ojg.2015.56040

[53] Maleki, Z., Arian, M. and Solgi, A. (2015) Folding Pattern in the Fars Province, Zagros Folded Belt: Case Study on the Karbasi and Khaftar Anticlines, Interior Fars, Iran. Solid Earth Discussions, 7, 2347-2379. https://doi.org/10.5194/sed-7-2347-2015

[54] Aram, Z. and Arian, M. (2016) Active Tectonics of the Gharasu River Basin in Zagros, Iran, Investigated by Calculation of Geomorphic Indices and Group Decision Using Analytic Hierarchy Process (AHP) Software. Episodes, 39, 39-44. https://doi.org/10.18814/epiiugs/2016/v39i1/89235

[55] Abdolizadeh, S., Maleki, Z. and Arian, M. (2016) Earthquake Hazard Zonation and Seismotectonics of the Bandar Abbas Area, Zagros, Iran. Open Journal of Geology, 6, 210-224. https://doi.org/10.4236/ojg.2016.63019

[56] Hadizadeh, A., Arian, M. and Ganjouyan, M.A. (2011) Analysis Geometry Dashtak Detachment Zone in the Dashtak, Salamati and Sepidar Anticlines from Interior and Sub Coastal Fars Area. Journal of the Earth, 6, 33-44.

[57] Khodabakhshnezhad, A., Arian, M. and Pourkermani, M. (2008) The Elements of Fold Style Analysis in the Asmari Anticline (Zagros). Journal of Sciences, 18, 129138.

[58] Khodabakhshnezhad, A., Arian, M. and Pourkermani, M. (2015) Folding Mechanism in the Asmari Anticline, Zagros, Iran. Open Journal of Geology, 5, 197-208. https://doi.org/10.4236/ojg.2015.54018

[59] Arian, M., Pourkermani, M., Khodabakhshnezhad, A. and Noroozpour, H. (2011) Investigation of Oil Trap in the Asmari Anticline (Zagros, Iran). Indian Journal of Science and Technology, 4, 1696-1699.

[60] Dehbozorgi, M., Pourkermani, M., Arian, M., Matkan, A.A., Motamedi, H. and Hosseiniasl, A. (2010) Quantitative Analysis of Relative Tectonic Activity in the Sarvestan Area, Central Zagros, Iran. Geomorphology, 121, 329-341. https://doi.org/10.1016/j.geomorph.2010.05.002

[61] Rafiee, P., Baghbani, D., Aghanabati, A. and Arian, M. (2014) Micro Biostratigraphy and Lithostratigraphy of the Upper Permian Dalan Formation (Zagros Basin, Southwest Iran). International Journal of Geography and Geology, 3, 45-55.

[62] Arian, M. (2012) Salt Diapirism and Tectonics. 2nd Edition, Asar Nafis Press, Qum, $319 \mathrm{p}$.

[63] Maleki, Z., Arian, M., Solgi, A. and Ganjavian, M.A. (2013) Sediment Deformations 
on Strike Slip Fault Blocks and Analogue Modeling: A Case Study of the Nezamabad Fault, Interior Fars, Zagros. Journal of Sciences, 89, 39-51.

[64] Vaseghi, H., Maleki, Z. and Arian, M. (2016) Structural Style in the Zagros FoldThrust Belt: The Gavbast Anticline, Coastal Fars. Open Journal of Geology, 6, 109116. https://doi.org/10.4236/ojg.2016.62011

[65] Arian, M., Ahmadipour, M.R. and Khodaei, K. (2003) The Elements of Fold Style in Soltananticline, Northeast of Pole Dokhtar. Iranian Journal of Geology, 1, 1-8.

[66] Arian, M., Pourkermani, M., Qoreshi, M. and Ahmadnia, A. (2002) Salt Diapirism along Mengharak Fault System. Proceedings of the 6th Symposium of Geological Society of Iran, Kerman, 2-4 September 2002, 45-49.

[67] Manafi, M. and Arian, M. (2008) Basement Tectonics Investigation of Dezful Embayment, between Kazeron and Hendijan Faults. Journal of the Earth, 3, 47-61.

[68] Asghari, M.R., Mokhtari, M., Arian, M. and Vanaki, M.R. (2015) Pseudo 3D Seismic Data Interpretation and Inversion in Ferdowsi Oil Field, Persian Gulf. Geosciences, 24, 341-348.

[69] Badrkhani, M., Maleki, Z. and Arian, M. (2016) Folding Style Analysis of the Tabnak Sweet Gas Field, Zagros, Iran. Open Journal of Geology, 6, 971-981. https://doi.org/10.4236/ojg.2016.68073

[70] Alladin, Y., Talebian, M., Arian, M. and Ahmadi, M.M. (2015) Geotechnical Investigation and Seismic Zonation of Alluvial Deposits in Western Tehran. Geosciences, 24, 333-342.

[71] Taherkhani, B., Nazari, H., Pourkermani, M. and Arian, M. (2015) Geometry and Recent Kinematics of the North Qazvin Fault: Morphotectonic Approach. Geosciences, 24, 29-38.

[72] Manuchehri, H., Arian, M., Ghorashi, M., Solgi, M. and Sorbi, A. (2015) Geomorphic Signatures of Active Tectonics in the Chalus Drainage Basin in the Alborz, Iran. Geosciences, 24, 273-280.

[73] Noroozpour, H., Arian, M. and Sorbi, A. (2015) Fault Movement Potentials in the Tehran-Semnan Region (North Iran). Open Journal of Geology, 5, 281-290. https://doi.org/10.4236/ojg.2015.55025

[74] Arian, M., Maleki, Z. and Noroozpour, H. (2011) Cenozoic Diastrophism and Deformational Events in the East Central Alborz. Journal of Basic and Applied Scientific Research, 1, 2394-2400.

[75] Feizi, F., Arian, A. and Rahmani, R. (2007) Seismotectonic Zoning in the Eastern Part of the Central Alborz. Journal of Sciences, 17, 151-164.

[76] Khavari, R., Arian, M. and Ghorashi, M. (2009) Neotectonics of the South Central Alborz Drainage Basin, in NW Tehran, N Iran. Journal of Applied Sciences, 9, 4115-4126. https://doi.org/10.3923/jas.2009.4115.4126

[77] Arian, M. and Bagha, N. (2012) Active Tectonics of Tehran Area, Iran. Journal of Basic and Applied Scientific Research, 2, 3805-3819.

[78] Bagha, N., Arian, M., Ghorashi, M., Pourkermani, M., El Hamdouni, R. and Solgi, A. (2014) Evaluation of Relative Tectonic Activity in the Tehran Basin, Central Alborz, Northern Iran. Geomorphology, 213, 66-87. https://doi.org/10.1016/j.geomorph.2013.12.041

[79] Arian, M. and Feyzi, F. (2005) Application of Geomorphic Indices to the Assessment of Relative Tectonic Activity Levels in the Alborz-Central Iran Border Zone. Journal of Sciences, 15, 378-403.

[80] Arian, M., Bagha, N., Khavari, R. and Noroozpour, H. (2012) Seismic Sources and Neo-Tectonics of Tehran Area (North Iran). Indian Journal of Science and Techno- 
$\log$, 5, 2379-2383.

[81] Moghimi, H., Arian, M. and Sorbi, A. (2015) Fault Movement Potential of Marzanabad Area, North Alborz, Iran. Open Journal of Geology, 5, 126-135. https://doi.org/10.4236/ojg.2015.53012

[82] Arian, M. and Pourkermani, M. (2004) Tectonic Elements of South Flank in the East-Central Alborz Mountain. Journal of Sciences, 4, 359-368.

[83] Arian, M. and Qorashi, M. (2006) The Movement Potential Evaluation of the Major Quaternary Faults in Alborz-Central Iran Border Zone, from the East of Tehran to the East of Semnan. Journal of Geosciences, 15, 184-188.

[84] Poroohan, N., Pourkermani, M. and Arian, M. (2013) An Assessment of Relationship in F-Parameter and Paleostress Fields in Heterogeneous Lithologies: Roudbar Area (Northwest of Iran). Australian Journal of Basic \& Applied Sciences, 7, $933-$ 942.

[85] Poroohan, N., Poukermani, M. and Arian, M. (2009) An Assessment on Correlations of Seismotectonic Parameters Preceding and Following Roudbar-Manjil Earthquake (Gilan, North of Iran). Australian Journal of Basic \& Applied Sciences, 3, 2643-2652.

[86] Farrokhnia, A.R., Pirasteh, S., Pourkermani, M. and Arian, M. (2011) Geo-Information Technology for Mass Wasting Hazard Zonation: Central-West Alborz-Iran. Disaster Advances, 4, 24-33.

[87] Khavari, R., Ghorashi, M. and Arian, M. (2009) Assessment of Relative Active Tectonics, South Central Alborz (North Iran). EGU General Assembly Conference $A b$ stracts, 11, 1137.

[88] Sorbi, A., Arian, M. and Pourkermani, M. (2009) The Movement Potential Evaluation of the Major Quaternary Faults in Tehran Quadrangle. Journal of the Earth, 19, 176-182.

[89] Feizi, F. and Arian, M. (2006) The Classification of Thrust Fronts in the AlborzCentral Iran Border Zone from the East of Varamin to the East of Semnan. Journal of Sciences, 16, 75-87.

[90] Arian, M. and Pourkermani, M. (2004) Structural Significance of North Semnan and Attary Faults in Alborz-Central Iran Border Zone. Journal of Science, 14, 45514569.

[91] Arian, M. and Pourkermani, M. (2005) Cenozoic Diastrophism and Deformational Events in the Southern Flank of Central-East Alborz. Journal of Faculty Earth Sciences, 10, 43-51.

[92] Sadeghi, R., Saeedi, A., Arian, M., Ghorashi, M. and Solgi, A. (2015) Comparison of Strain Ellipsoid Shape in the South of Ardabil Range (NW), Based on the Results of the Magnetic Susceptibility Anisotropy and Paleostress Methods. Open Journal of Geology, 5, 611-622. https://doi.org/10.4236/ojg.2015.59054

[93] Arian, M., Pourkermani, M., Qorashi, M. and Ghasemi, M.R. (2003) North Semnan Fault System and Its Role on Basin Division. Proceedings of the 8 th Symposium of Geological Society of Iran, Shahrood, 4-6 September 2003, 11-17.

[94] Pourkermani, M. and Arian, M. (2001) Structural Geomorphology of Northeastern Kurdistan. Journal of Humanities, 7, 37-48.

[95] Mardani, Z., Ghorashi, M. and Arian, M. (2011) Geomorphic Signatures of Active Tectonics in the Talaghanrud, Shahrudand Sefidrud Drainage Basins in Central Alborz, N Iran. Geosciences, 20, 159-166.

[96] Sorbi, A., Arian, M. and Pourkermani, M. (2011) The Application of Geomorphic Indices to the Assessment of Relative Tectonic Activity Levels in Tehran Quadran- 
gle. Journal of the Earth, 6, 1-9.

[97] Khavari, R., Ghorashi, M., Arian, M. and Khosrotehrani, K. (2010) Geomorphic Signatures of Active Tectonics in the Karaj Drainage Basin in South Central Alborz, N Iran. Geosciences, 19, 67-74.

[98] Mousavi, E.J. and Arian, M. (2015) Tectonic Geomorphology of Atrak River, NE Iran. Open Journal of Geology, 5,106-114. https://doi.org/10.4236/ojg.2015.53010

[99] Nouri, R., Jafari, M.R., Arian, M., Feizi, F. and Afzal, P. (2013) Correlation between $\mathrm{Cu}$ Mineralization and Major Faults Using Multifractal Modelling in the Tarom Area (NW Iran). Geologica Carpathica, 64, 409-416. https://doi.org/10.2478/geoca-2013-0028

[100] Nouri, R., Jafari, M.R., Arian, M., Feizi, F. and Afzal, P. (2013) Prospection for Copper Mineralization with Contribution of Remote Sensing, Geochemical and Mineralographical Data in Abhar 1:100,000 Sheet, NW Iran. Archives of Mining Sciences, 58, 1071-1084. https://doi.org/10.2478/amsc-2013-0074

[101] Nouri, R., Afzal, P., Arian, M., Jafari, M. and Feizi, F. (2013) Reconnaissance of Copper and Gold Mineralization Using Analytical Hierarchy Process in the Rudbar 1:100,000 Map Sheet, Northwest Iran. Journal of Mining and Metallurgy, 49, 9-19.

[102] Farrokhnia, A.R., Pirasteh, S., Pradhan, B., Pourkermani, M. and Arian, M. (2011) A Recent Scenario of Mass Wasting and Its Impact on the Transportation in Alborz Mountains, Iran Using Geo-Information Technology. Arabian Journal of Geosciences, 4, 1337-1349. https://doi.org/10.1007/s12517-010-0238-7

[103] Arian, M. and Nouri, R. (2015) Lineament Tectonics and Mineralization in Tarom Area, North Iran. Open Journal of Geology, 5, 115-124.

https://doi.org/10.4236/ojg.2015.53011

[104] Feizi, F. and Arian, M. (2011) The Role of Structural Controllers in Geneses of Copper Deposits in 1:50000 Map of Saiin Qaleh. Journal of Sciences, 21, 1-10.

[105] Bahiraee, S., Arian, M., Qorashi, M. and Solgi, M. (2015) The Movement Potential Evaluation of the Mosha Fault (the West of Firoozkuh to the Shahrestanak). Geosciences, 24, 123-126.

[106] Bagha, N., Ghorashi, M., Arian, M., Pourkermani, M. and Solgi, A. (2015) Neotectonic Analysis of Mosha-North Tehran Fault Zone, Based on Morphotectonic Features, Central Alborz, Northern Iran. Geosciences, 24, 41-52.

[107] Mosavi, E. and Arian, M. (2015) Neotectonics of Kashaf Rud River, NE Iran by Modified Index of Active Tectonics (MIAT). International Journal of Geosciences, 6, 776-794. https://doi.org/10.4236/ijg.2015.67063

[108] Nouri, R. and Arian, M. (2015) Structural Control on the Distribution of Hydrothermal Alteration Zones and Mineralization in Dastjerdeh Area Based on Remote Sensing Data, NW Iran. Bulletin of the Georgian National Academy of Sciences, 9 , 79-86.

[109] Khosroshahizadeh, S., Pourkermani, M., Almasiyan, M., Arian, M. and Khakzad, A. (2015) Evaluation of Structural Patterns and Related Alteration and Mineralization Zones by Using ASAR-ASTER Imagery in Siyahrood Area (East Azarbaijan-NW Iran). Open Journal of Geology, 5, 589-610. https://doi.org/10.4236/ojg.2015.59053

[110] Pahlavani, A., Pourkermani, M., Arian, M. and Vahabzadeh, G. (2010) Structural Analysis of Emaft Fluorite Mine Region (SavaadKuh Mazandaran). Journal of the Earth, 5, 75-81.

[111] Bazarchi, S., Jafari, M.R. and Arian, M. (2012) Geochemical Studies and Introduction of Anomaly Zones in Kandelus Sheet (Southwest of Baladeh). Journal of the Earth, 6, 67-75. 
[112] Bagheri, M., Feiznia, S., Arian, M., Shabanian, R. and Mahari, R. (2013) Continental Trace Fossils in the Semnan Area (Northern Iran). Open Journal of Geology, 3, 5461. https://doi.org/10.4236/ojg.2013.32009

[113] Manafi, M., Arian, M., Raeesi, S. and Solgi, A. (2013) Tethys Subduction History in Caucasus Region. Open Journal of Geology, 3, 222-232. https://doi.org/10.4236/ojg.2013.33026

[114] Khosroshahizadeh, S., Pourkermani, M., Almasian, M., Arian, M. and Khakzad, A. (2016) Lineament Patterns and Mineralization Related to Alteration Zone by Using ASAR-ASTER Imagery in Hize Jan-Sharaf Abad Au-Ag Epithermal Mineralized Zone (East Azarbaijan-NW Iran). Open Journal of Geology, 6, 232-250. https://doi.org/10.4236/ojg.2016.64021

[115] Mousavi, E., Arian, M. and Ghorashi, M. (2017) Investigation of T Factor Variations along Atrak River to the Caspian Sea. Open Journal of Marine Science, 7, 35 50. https://doi.org/10.4236/ojms.2017.71004

[116] Yahyaee, H.N., Arian, M., Pourkermani, M. and Sorbi, A. (2010) Investigating and Analyzing the Present Lineaments in Tehran Quadrangle by Remote Sensing. Journal of Science, 5, 145-161.

[117] Sistanipour, A. and Arian, M. (2015) Geometric Analysis of Davaran Fault System, Central Iran. Open Journal of Geology, 5, 458-469. https://doi.org/10.4236/ojg.2015.56043

[118] Nazemi, M., Ghorashi, M., Ghassemi, M.R. and Arian, M. (2015) Morphotectonics Features of Alluvial Fans Associated with Active Tectonics (Shotori Mountains, East of Tabas-Central Iran). Geosciences, 24, 91-100.

[119] Alizadeh, H. and Arian, M. (2015) Rule of Structural Factors in Formation of Porphyry Copper Deposits in South Western Part of Kerman Area, Iran. Open Journal of Geology, 5, 489-498. https://doi.org/10.4236/ojg.2015.57045

[120] Mosavi, E.J. and Arian, M. (2015) Neotectonics of Tabas Area, Central Iran by Index of Active Tectonics (IAT). Open Journal of Geology, 5, 209-223. https://doi.org/10.4236/ojg.2015.54019

[121] Daryani, N.J., Arian, M. and Omran, N.R. (2015) Tectonics and Mineralization of Copper in the Ardestan-Kahang Area, Central Iran by Remote Sensing. Open Journal of Geology, 5, 188-196. https://doi.org/10.4236/ojg.2015.54017

[122] Arian, M. and Pourkermani, M. (2001) Rivers Morphology and Active Tectonic (Reviewing the Current Status of Ghezel Ozon River in the Province of Zanjan). Proceedings of the 5 th Conference of Geological Society of Iran, Tehran, 28-30 August 2001, 556.

[123] Eshghi, Z., Arian, M. and Pourkermani, M. (2012) Structural Investigation on the Lak Mining Area (Bueen Zahra) Based on Remote Sensing, Used for Its Mineralization. Journal of the Earth, 6, 145-155.

[124] Arian, M., Toudeshki, V.H. and Noroozpour, H. (2011) Active Tectonics of Qezel Ozan River Basin, NW Iran. Journal of Applied Environmental and Biological Sciences, 1, 291-295.

[125] Alizadeh, H., Arian, M., Lotfi, M., Ghorashi, M. and Ghorbani, M. (2015) Determination of Porphyry Copper Deposit Locations Using Photo Lineament Factor in Northern Parts of the Dehaj-Sardoiyeh Belt. Geosciences, 24, 247-252.

[126] Toudeshki, V.H., Pourkermani, M., Arian, M. and Khosrotehrani, K.H. (2011) Influence of Structures on the Ghezel Ozan River. Geosciences, 21, 55-60.

[127] Toudeshki, V.H. and Arian, M. (2011) Morphotectonic Analysis in the Ghezel Ozan River Basin, NW Iran. Journal of Geography and Geology, 3, 258-260. 
https://doi.org/10.5539/jgg.v3n1p258

[128] Arian, M. (2015) Seismotectonic-Geologic Hazards Zoning of Iran. Earth Sciences Research Journal, 19, 7-13. https://doi.org/10.15446/esrj.v19n1.40664

[129] Arian, M., Pourkermani, M., Sistanipour, A. and Noroozpour, H. (2011) Kinematic Significance of Fold- and Fault-Related Fracture Systems in the Rafsanjan's Northeast Highlands (Central Iran). Journal of Basic and Applied Scientific Research, 1, 3398-3406.

[130] Arian, M., Pourkermani, M., Sistanipour, A. and Noroozpour, H. (2011) Seismicity and Fault Segmentation of Bafq-Baghin Fault System (Central Iran). Journal of Applied Environmental and Biological Sciences, 1, 382-396.

[131] Mosavi, E.J., Arian, M., Ghorashi, M. and Nazemi, M. (2012) Measurements of Geomorphic Indices in Tabas Area. Journal of the Earth, 7, 213-225.

[132] Arian, M. (2010) Earthquake-Fault Hazard Investigations in the Kerman Quadrangle. Journal of Sciences, 19, 176-182.

[133] Arian, M. and Sorbi, A. (2011) Remote Sensing Investigation of the Faults and Lineaments in the Karaj-Qazvin Region. Journal of the Earth, 5, 21-34.

[134] Arian, M., Alizadeh, H. and Noroozpour, H. (2011) Satellite Geometry of Faults and Fractures and Its Relationship with Porphyry Deposits in Northern Parts of DahajSardoiyeh Belt, South of Iran. Indian Journal of Science and Technology, 4, 13031306.

[135] Pourkermani, M., Mohajjel, M., Solgi, A., Arian, M. and Nadri, R. (2013) Active Tectonics of South Qom. Applied Geology, 8, 203-213.

[136] Noroozpour, H., Rad, Y.M., Arian, M., Solgi, A. and Vafa, N.N. (2013) Permo-Triassic Deposits of Shorjestan Area, Central Iran: The Palynological Report of the Greatest Phanerozoic Disaster in Iran. Disaster Advances, 6, 48-53.

[137] Mirzeinaliyazdi, S.H., Pourkermani, M., Arian, M. and Almasian, M. (2012) Geometrical Analysis of Fractures in Sabzevar Ophiolite Zone. Journal of Geotechnical Geology (Applied Geology), 7, 359-371.

[138] Pourkermani, M., Mohajjel, M., Solgi, A., Arian, M. and Nadri, R. (2012) Active Tectonics of South Qom, a Hazard for New Residential Areas. Journal of Geotechnical Gology (Applied Geology), 8, 203-213.

[139] Pourkermani, M. and Arian, M. (2016) Analysis of Structural Specifications in Shah Neshin Area (the Eastern Border of Kordestan Province). Journal of Sciences, 11, 2859-2869.

[140] Yazdi, S.H.M., Pourkermani, M., Arian, M. and Karkheiran, A. (2012) Determination of Stress Orientation in Sabzevar Ophiolite Zone in (Khorasan Razavi Province, Iran). Indian Journal of Science and Technology, 5, 3500-3505.

[141] Keynezhad, A., Pourkermani, M., Arian, M., Saeedi, A. and Lotfi, M. (2010) Research on Fractures in North of the Torud-Moalleman Area (Central Iran, Southeastern of Damghan) and Their Relation with Mineralization. Journal of the Earth, 5, 81-97.

[142] Mahmoodi, M., Bahroudi, A., Ghorbani, M. and Arian, M. (2013) Preliminary Exploration of Copper Minerals in Jebal Barez Mountains, Iran. Open Journal of Geology, 3, 201-208. https://doi.org/10.4236/ojg.2013.33023

[143] Keynezhad, A., Pourkermani, M., Arian, M. and Saeedi, A. (2011) Dynamic Analysis of Fractures in North of Torud-Moalleman Area (Central Iran, East South of Damghan). Geosciences, 20, 3-16.

[144] Pourkermani, M., Qorashi, M., Arian, M., Sorbi, A., Farokhnia, A. and Solgi, A. 
(2003) Structural Features in Western Part of the Lut Region. Iranian Journal of Geology, 1, 29-44.

[145] Arian, M. (2003) Seismotectonic and Earthquake-Fault Hazard Investigations in the Kerman Region. Research Institute of Applied Sciences.

Submit or recommend next manuscript to SCIRP and we will provide best service for you:

Accepting pre-submission inquiries through Email, Facebook, LinkedIn, Twitter, etc. A wide selection of journals (inclusive of 9 subjects, more than 200 journals)

Providing 24-hour high-quality service

User-friendly online submission system

Fair and swift peer-review system

Efficient typesetting and proofreading procedure

Display of the result of downloads and visits, as well as the number of cited articles

Maximum dissemination of your research work

Submit your manuscript at: http://papersubmission.scirp.org/

Or contact ojg@scirp.org 